\title{
A beltenyésztett cirok vonalak és kétvonalas hibridjeik egyes beltartalmi tulajdonságainak vizsgálata
}

\author{
PEPÓ PÁL-ERDEI ÉVA-KOVÁCSNÉ OSKOLÁS HENRIETTT- \\ TÓTH SZILÁRD-SZABÓ ERZSÉBET \\ Debreceni Egyetem AGTC Kertészettudományi Intézet,
} Növényi Biotechnológiai Tanszék, Genetikai és Nemesítési Csoport, Debrecen

\begin{abstract}
Összefoglalás
A nagy mennyiségú növényi biomassza előállításához EU-konform energianövények szükségesek. Ilyen speciális biológiai alap a cirok is. A bioetanol célú felhasználás legfontosabb ígénye a területegységenként kinyerhetô minél nagyobb etanol kihozatal. Ennek komponensei: a magas termőképesség, az ezerszemtömeg, a keményítôtartalom és minőség, valamint a szemtermésben található keményító-és fehérjetartalom aránya. A Kertészettudományi Intézet bemutatókertjében 2008-ban saját elóállítású, kétvonalas cirokhibrideket vetettünk el. Célkitúzésünk az volt, hogy meghatározzuk a low input technológiával termesztett hibridek esetében a heterózis és a heterobeltiózis mértékét a keményítőre, a fehérjére, valamint az ezerszemtömegre nézve. Vizsgáltuk a beltartalmi mutatók közötti korrelációt. Az analízist a DA 7200 diódasoros NIR spektrométerrel végeztük.

A keményítőtartalom a kísérleti hibridek esetében 48,37-62,63\% közötti intervallumban változott a vizsgált paraméter tekintetében. A hibridek között szignifikáns különbségeket találtunk. A legnagyobb érték az $S L_{1} x R L_{12}$ hibridet jellemezte. A nyersfehérjetartalom 9,43-17,7\% szélsőértékek között változott, a legnagyobb értéket az $S L_{1} x R L_{10}$ esetében mértük. Negatív korrelációt találtunk a keményító és a nyersfehérjetartalom között ( $\left.\mathrm{r}=-0,9412^{* * *}\right)$. A jobbik szülő átlagát mind fehérje, mind keményítőtartalomra nézve egyik hibrid sem haladta meg, tehát negatív heterobeltiózist tapasztaltunk. Minden hibridnél pozitív átlagos- és abszolut heterózishatás volt tapasztalható a keményítôtartalomra nézve.
\end{abstract}


A keményítoore nézve pozitív volt az átlagos heterózis (1,9\%), csakúgy, mint az ezerszemtömeg esetében $(29,09)$, ennél a tulajdonságnál még pozitív heterobeltiózis is érvényesült.

Kulcsszavak: cirokhibridek, heterózis, heterobeltiózis, keményítôtartalom, proteintartalom

\title{
Examination of the nutritional values of inbred sorghum lines and their single cross sorghum hybrids
}

\author{
P. PEPÓ-É. ERDEI-H. KOVÁCSNÉ OSKOLÁS-SZ. TÓTH-E. SZABÓ \\ University of Debrecen Centre for Agricultural and Applied Economic Sciences, \\ Institute of Horticulture, Department of Plant Biotechnology, \\ Genetics and Plant Breeding Group, Debrecen
}

\begin{abstract}
Summary
To produce large amounts of biomass, EU conform energy plants are needed, such as sorghum. The most important factor is the highest ethanol yield per area which depends on high productivity, starch content and quality, starch/protein ratio in grain crop. We have sown own single cross sorghum hybrids in 2008 in the experimental garden of the Institute of Horticulture. Our aim was to determine the heterosis and heterobeltiosis of hybrids produced by low input technology from the aspects of starch, protein and thousand kernel weights. We examined the correlation between the nutritional values. The analysis was carried out by a DA 7200 diode array NIR spectrometer. We have performed correlation studies between nutritional values.

The starch contents of single cross hybrids varied between $48.37 \%$ and $62.63 \%$ in the case of the examined parameters. We have found significant differences between hybrids. The highest content was found in case of $S L_{1} x R L_{12}$. The protein content ranged between $9.43-17.7 \%$ and the highest value was observed in the case of $S L_{1 x} R L_{10}$. A negative correlation was found between the starch and protein content $(\mathrm{r}=-0.9412 * * *)$. The mean value of the best lines was not exceeded by any of the hybrids, thus, a negative heterosis was found. As for of starch content, positive mean and absolute heterosis effects were found in the case of all hybrids.
\end{abstract}


The average heterosis (1.9\%) was positive from the aspect starch. In the case of thousand kernel weight, the average heterosis $29.09 \%$ was positive, whereas the heterobeltiosis was also positive.

Key words: sorghum hybrids, heterosis, heterobeltiosis, starch content, protein content

\title{
Исследование некоторых свойств внутреннего содержания линий и двухлинейных гибридов инцухтированного сорго
}

\author{
П. ПЕПО-Е. ЭРДЕИ-Г. КОВАЧНЕ ОШКОЛАШ-С. ТОТ-Э. САБО \\ Дебреценский Университет, Институт Садоводства Центра Агро-Экономических \\ Наук, Кафедра Растительной Биотехнологии, Группа Генетики и Селекци, \\ Дебрецен
}

\section{Резюме}

Для производства большого количества растительной биомассы необходимые принятые ЕС энергетические растения. Такой специальной биологической основой является также и сорго. Самое важное требование использования для получения биоэтанола - выход как можно большего количества этанола с единицы территории. Компоненты этого: высокое плодородие, масса тысячи зёрен, содержание крахмала и его качество, а также соотношение содержания крахмала и белка в урожае зерна. В демонстрационном саду Садоводческого Научного Института в 2008 году посадили своего изготовления, двухлинейные гибриды сорго. Нашей целью было установить в случае гибридов, выращенных технологией low input, величину гетерозиса и гетеробелтиозиса (heterobeltiózis) на крахмал, на белок, и также на массу тысячи зёрен. Изучали корреляцию между показателями внутреннего содержания. Анализ проводили DA 7200 диодорядным NIR спектрометром.

Содержание крахмала в случае опытных гибридов изменялось в интервале 48,37-62,63\% в отношении исследованного параметра. Среди гибридов обнаружили значительные различия. Самый большой показатель характеризовал гибрид $S L_{1} x R L_{12}$. Содержание сырого белка изменялось в рамках крайних показателей 9,43-17,7\%, самую большую величины измерили в случае $S L_{1} x R L_{10}$. Обнаружили негативную 
корреляцию между содержанием крахмала и сырого белка $(\mathrm{r}=-0,9412 * * *)$. Среднюю величину лучшего родителя как по содержанию белка,так и по содержанию крахмала ни один из гибридов не превысил, т.е. обнаружили негативный гетеробелтиозис. У каждого гибрида позитивное среднее и абсолютное влияние гетерозиса было обнаружено касательно содержания крахмала.

Рассматривая крахмал позитивным был средний гетерозис (1,9\%), также как и в случае массы тысячи зёрен $(29,09)$, в этом свойстве также и позитивный гетеробелтиозис проявился.

Ключевые слова: гибриды сорго, гетерозис, гетеробелтиозис, содержание крахмала, содержание белка

\section{Bevezetés}

Az energetikai célú biomassza termelés jelentősége fokozatosan növekszik a klímaváltozás és az energiahordozók importja miatt. A bioetanol előállítás céljaira nemesített, nagy keményítôtartalmú és alacsony fehérjetartalmú cirokhibridek low input rendszerben is termeszthetők. A minôséget meghatározó beltartalmi összetevők közül, a fehérje-, az olaj- és a keményítôtartalmat nemesítéssel számottevốn lehet befolyásolni. A bioetanol célú felhasználás legfontosabb ígénye a területegységenként kinyerhetô legnagyobb etanol kihozatal. Ennek komponensei: a nagy termôképesség, a keményítôtartalom, a keményítô minôsége (amilóz-, amilopektin arány), valamint az erjeszthetôség. Az erjeszthetôség megállapítása laboratóriumi körülmények között költséges, ezért a nemesítő munka során molekuláris markerezéssel célszerú kiválasztani a legjobb etanol kihozatalt ígérô genotípusokat. A cirok a szélsôségesen száraz területeken a kukorica alternatívája lehet önmagában vagy kukoricával együtt vetve. E növényfaj tekintetében ugyan kevés eredmény áll rendelkezésre, potenciálisan bioetanol és biogáz elóállítására egyaránt felhasználható. A cirok szárában könnyen emészthetố szénhidrátok találhatók, amelyekból az éréshez közeledve keményítô képzôdik a szemtermésben. Az etanolgyártás szempontjából lényeges a szemtermésben található keményítôtartalom meghatározása és korrelációja a fehérjével. 
A NIR-technika a minta fizikai paramétereinek kémiai jellemzőkkel történô korreláltatására alkalmas. A közeli infravörös tartományban mért spektrumértékekbôl a fehérje és a keményítő meghatározható. A laboratóriumi enzimes vizsgálatok költségeinek csökkentését szolgálja a NIR-technikával meghatározható beltartalmi vizsgálat. A NIR készülék a vizsgált mintáról rövid idő alatt nagy mennyiségú információt szolgáltat, melynek értékelése matematikai-statisztikai módszerekkel történik. A cirokhibridek esetében a heterózishatás megmutatkozik a szülő vonalakhoz képest a korai virágzásban, a növénymagasságban és a hektáronkénti szemtermés- és biomassza hozamban.

\section{Irodalmi áttekintés}

A NIR-készülékkel analizált magas fehérje-emészthetôséggel rendelkező cirok rekombináns beltenyésztett vonalak (RILs) esetében a fehérjetartalom magas, míg a keményítôtartalom ezzel összefüggésben alacsonyabb. A cirok vonalak fehérje emészthetôsége növekszik, a keményítőtartalma csökken. A vizsgált rekombináns beltenyésztett vonalak proteintartalma 11,51-14,35\%-ig terjed, míg a keményítôtartalma 68,46-72,32\%-ig (Joan et al. 2008). A keményítőtartalomnál a divergens szelekció eredményesen alkalmazható. A szelekció segítségével a keményítőtartalom növelhető (Eyherabide et al. 1995).

A Perten PDA 7000 NIR készülékkel cirokmagot vizsgáltak. A vizsgálat során a fehérje és a keményítő összetevőket korreláltatták és az r-értékek a következők voltak: -0,923 és -0,950 (Donough és Rooney 2007). Kiemelkedôen nagyobb fehérjetartalmat mértek a kukorica ôsénél (teosinte), mint a jelenleg termesztett kukorica hibrideknél. A teosinte, a tájfajták, és a kukorica beltenyésztett vonalak magösszetételét összehasonlítva megállapították, hogy magasabb volt a teosinte proteintartalma, és alacsonyabb a szénhidráttartalma, mint a tájfajtáknak és a beltenyésztett vonalaknak. A vizsgált teosinok átlagos proteintartalma 28,71\%, szénhidráttartalma 52,92\% volt. A kísérletbe vont kukorica-tájfajták proteintartalmának átlaga 12,13\%, és a szénhidráttartalmának átlaga 71,16\% volt. A vizsgálatban szereplő kukorica beltenyésztett vonalak átlagos fehérjetartalma 11,11\% volt, míg a szénhidráttartalom 72,37\%-os volt (Sherry et al. 2009).

Thokoza (2005) dél-afrikai cirok $\mathrm{F}_{1}$-hibridek, és azok szülöi vonalát értékelte, valamint heterózist számoltak. Nagy heterózis volt tapasztalható a hektáronkénti hozamban (37,18\%), a növénymagasságban (23,7\%), míg alacsony teljes virágzási 
időben ( $0,02 \%)$. Az átlagos heterózis- a fehérjetartalomra nézve negatív értéket mutatott (-12,35\%). A hibrideknek alacsonyabb volt a fehérjetartalma, mint a szülói vonalaknak. A kísérletben gyenge negatív korrelációt találtak a fehérjetartalom és a terméshozam között $\left(-0,35^{* *}\right)$.

A szénhidráttartalom a cirokmagok legnagyobb részénél 70-90\%. A fehérjetartalom értékei széles határok között mozogtak (7,1-21,5\%), míg a legmagasabb érték $21,5 \%$ volt.

A hibrideket és a szüleiket összehasonlítva a következô mennyiségi tulajdonságoknál találtak heterózist a cirokban: virágzás, növénymagasság, oldalhajtás, szárátmérô, buga mérete, hektáronkénti hozam (Thokoza 2005).

A fehérje tápértékét kétféle cirokmintában vizsgálták. Az egyik mintacsoport fehérjetartalma 7,9\%, míg a másik csoport fehérjetartalma $11,8 \%$ volt. A nagy fehérjetartalmú mintacsoportban mind a 17 féle aminosav nagyobb értéket mutatott, mint a kisebb fehérjetartalmú csoport. Mindkét mintában a lizin volt a leghiányosabb aminosav és a kéntartalmú aminosavak, valamint a threonin is alacsony volt (Doyle et al. 2010). A fehérje frakciókat tanulmányozták kísérletben Mohammad et al. (1979) 8,6-18,2\% fehérjét tartalmazó cirokmintákban, $17,5-220$ ppm N-ellátottság mellett. A N-ellátottság növekedésével az albumin globulin tartalom csökkent, míg a prolamin glutelin ellátottság nôtt. A nyersfehérje egyike a vetômagban található legfontosabb kémiai összetevốknek. A nyersfehérje negatív korrelációban van a két másik összetevốvel, a keményítôvel és az olajjal (Yuling et al. 2009). Hicks et al. (2002) vizsgálták nyolc szemes cirok vonal és a hibridjeik nyersfehérje, nyerszsír, keményítő és fehérje emészthetôségét NIR-készülékkel, valamint mérték a magtömeg hatását a felsorolt minôségi paraméterekre. Szoros negatív korrelációt találtak a nyersfehérjetartalom és a keményítôtartalom, valamint a keményítótartalom és a magtömeg között. Szoros pozitív korrelációt találtak a nyersfehérjetartalom és a magtömeg között.

BR007AA $\times$ BR012R és BR001A × BR012R szemescirok hibridnél pozitív heterózist állapítottak meg a terméseredményre, szárazanyaghozamra, és negatív heterózis volt a nyersfehérje és a nyersrost között (Thokoza 2005).

Mohammad et al. (1993) 54 db szemes cirok genotípust vizsgáltak. A magas takarmányhozam korrelációt mutatott a késói éréssel, nagyobb bokrosodó képességgel, de alacsony nyersfehérjetartalmat és harvest index mutatót kaptak. A termóképesség kapcsolatban volt a nagy harvest indexszel, a nagyobb vetômag számmal és mérettel, valamint alacsony növénymagassággal. A 
nagy nyersfehérje tartalom korrelált a nagy harvest indexszel és alacsony növénymagassággal, több savdetergens rostot mértek és korrelációt tapasztaltak a nagyobb növénymagassággal. A késôi érés és a nagyobb növénymagasság korrelált a magas harvest indexszel.

\section{Anyag és módszer}

A Kertészettudományi Intézet bemutatókertjében, 2008-ban saját előállítású kétvonalas cirokhibrideket vetettünk el. A genetikai hátteret az 1. táblázat tartalmazza. Célkitűzésünk az volt, hogy meghatározzuk a low input technológia mellett termesztett hibridek esetében a heterózis mértékét a keményítőre és a fehérjére, valamint az ezermagtömegre.

1. táblázat. A vizsgált cukorcirok genotípusok köre

\begin{tabular}{|c|c|c|c|c|c|}
\hline $\begin{array}{l}\text { Hibridek } \\
\text { (1) }\end{array}$ & $\begin{array}{c}\text { Kódok jelentése } \\
\text { (2) }\end{array}$ & $\begin{array}{c}\text { Anyai } \\
\text { vonal } \\
(3)\end{array}$ & $\begin{array}{c}\text { Kódok } \\
\text { jelentése } \\
\text { (2) }\end{array}$ & $\begin{array}{c}\text { Apai } \\
\text { vonal } \\
(4)\end{array}$ & $\begin{array}{c}\text { Kódok jelentése } \\
\text { (2) }\end{array}$ \\
\hline $\mathrm{SL}_{1} \times \mathrm{RL}_{4}$ & RiaxSorgho sücré & \multirow{4}{*}{$\mathrm{SL}_{1}$} & \multirow{4}{*}{ Ria } & $\mathrm{RL}_{4}$ & Sorgho sücré \\
\hline $\mathrm{SL}_{1} \times \mathrm{RL}_{7}$ & RiaxMinnesota amber & & & $\mathrm{RL}_{7}$ & Minnesota amber \\
\hline $\mathrm{SL}_{1 \times R L_{10}}$ & RiaxOdeskoee Rannee & & & $\mathrm{RL}_{10}$ & Odeskoee Rannee \\
\hline $\mathrm{SL}_{1 \times \mathrm{RL}_{12}}$ & RiaxEarly sumac & & & $\mathrm{RL}_{12}$ & Early sumac \\
\hline
\end{tabular}

Table 1. The examined sweet sorghum genotype. (1) Hybrids, (2) Code, (3) Female lines, (4) Male lines.

A heterózis és a heterobeltiózis a következô két képlettel számolható ki:

Heterózis $=\frac{\left[\mathrm{F}_{1}-\left(\mathrm{P}_{1}+\mathrm{P}_{2}\right) / 2\right]}{\left(\mathrm{P}_{1}+\mathrm{P}_{2}\right) / 2} * 100$

$\mathrm{F}_{1}=\mathrm{a}$ hibrid vizsgált tulajdonságának átlaga

$\mathrm{P}_{1}=$ az egyik szülő vizsgált tulajdonságának átlaga

$\mathrm{P}_{2}=$ a másik szülố vizsgált tulajdonságának átlaga

Heterobeltiózis $=\frac{\left[\mathrm{F}_{1}-\mathrm{HP}\right] * 100}{\mathrm{HP}}$

HP = a legmagasabb szülői teljesítmény átlaga 
A heterózishatás mértékének meghatározása során azt vizsgáltuk, hogy a beltenyésztett vonalakkal létrehozott hibridkombinációk tulajdonságai / $\mathrm{F}_{1} /$ mennyivel haladják meg a szülők átlagát /P/abszolut értékben. Az átlagos heterózis során megállapítottuk a heterózishatás mértékét $/ \mathrm{F}_{1}-\mathrm{P} / \mathrm{P}$ a két szülő átlagához viszonyítva.

Meghatároztuk az egyes összetevôk százalékos arányát az összes szárazanyagon belül és a vizsgált beltartalmi mutatók között összefüggéseket vizsgáltunk. Az analízist a DA 7200 diódasoros NIR spektrométerrel végeztük. A mérési eredményeinket befolyásolhatják a magról nehezen leváló pelyvalevelek, amelyek a nemesítési alapanyagként szereplő vonalaknál előfordultak. A nehezen leváló pelyvaleveleket kézi kalászcséplôvel választottuk le a magról. A statisztikai értékeléshez az SPSS programcsomagot használtuk. Az eredmények kiértékelése többtényezôs varianciaanalízissel történt.

\section{Eredmények és azok kiértékelése}

A vizsgált vonalak keményítőtartalmának értékei 33,9-64,03\%-ig terjedtek. A legmagasabb értéket az $R L_{12}$ minta mutatta. A vonalak között találtunk szignifikáns különbséget, a keményítôtartalmat illetően az $\mathrm{SzD}_{5 \%}$ értéke 0,28 volt. A vonalak fehérjetartalma 8,27-23,10\%-ig terjedt. A legmagasabb értéket az $R L_{10}$ vonalnál mértük. A vonalak között különbség volt a fehérjetartalmat illetôen is, a szignifikáns differencia értéke 0,22 volt. A vonalak kiemelkedóen magas fehérjetartalmat mutattak, amelyből arra következtetünk, hogy ezek a cirok vonalak értékes nemesítési alapanyagok. Magas fehérjetartalmat mértünk az $R L_{4}$ és az $R L_{7}$ vonalnál, amelynek értékei 18,63\% és 19,83\% (2. táblázat). Ezen vonalak hibridjeinél a fehérjetartalom csökkent. Az $S L_{1} x R L_{4}$ hibrid fehérjetartalma 17,67\%-ra csökkent az apai vonalhoz képest, de pozitív heterózist számoltunk (3. táblázat). Az $S L_{1} x R L_{7}$ hibrid fehérjetartalma 12,7\%-ra csökkent és negatív heterózist is tapasztaltunk. A legmagasabb ezerszemtömeg átlagértéket az $R L_{7}$ vonalnál mértük, amely 31 g volt (2. táblázat). A keményítôtartalom értékek 48,37-62,63\% között változtak a kétvonalas hibridek esetében. $S L_{1} x R L_{12}$ hibridnél mértük a legmagasabb keményítőtartalmat és ezermagtömeget is $(32,7 \mathrm{~g})$. A keményítőtartalmat illetóen találtunk szignifikáns különbséget a hibridek között $\left(\mathrm{SzD}_{5 \%}=0,22\right)$. A fehérjetartalom intervalluma 9,43-17,7\% volt. Az $S L_{1} x R L_{10}$ hibrid értéke $17,7 \%$, amely a legnagyobb a vizsgált vonalak közül. A szignifikáns differencia értéke a fehérjetartalomra 0,25\% 
2. táblázat. A cirok restorer vonalak keményítô-, fehérjetartalma és ezermagtömege

\begin{tabular}{lcccc}
\hline \multicolumn{1}{c}{ Cirok } & Nedvesség & Keményító & Fehérje & Ezermagtömeg \\
vonalak (1) & $\%$ & $\%$ & $\%$ & $\mathrm{~g}$ \\
& $(2)$ & $(3)$ & $(4)$ & $(5)$ \\
\hline $\mathrm{RL}_{4}$ & 13,73 & 39,33 & 18,63 & 25,00 \\
$\mathrm{RL}_{7}$ & 14,00 & 33,90 & 19,83 & 31,00 \\
$\mathrm{RL}_{10}$ & 12,67 & 37,37 & 23,10 & 22,33 \\
$\mathrm{RL}_{12}$ & 10,70 & 64,03 & 8,27 & 20,00 \\
$\mathrm{SL}_{1}$ & 11,57 & 58,9 & 11,23 & 30,66 \\
$\mathrm{SzD}_{5 \%}(6)$ & 0,11 & 0,28 & 0,22 & \\
\hline
\end{tabular}

Table 2. Starch-, protein content and kernel weight of sorghum restorer lines. (1) Sorghum lines, (2) Moisture, (3) Starch, (4) Protein, (5) Thousand kernel weight, (6) $\mathrm{LSD}_{5 \%}$.

3. táblázat. A kétvonalas cukorcirok hibridek keményítô-és fehérjetartalma, valamint ezerszemtömege

\begin{tabular}{|c|c|c|c|c|}
\hline Cirok & Nedvesség & Keményítő & Fehérje & Ezermagtömeg \\
\hline hibridek & $\%$ & $\%$ & $\%$ & $\mathrm{~g}$ \\
\hline (1) & (2) & (3) & (4) & (5) \\
\hline $\mathrm{SL}_{1} \times \mathrm{RL}_{4}$ & 12,03 & 52,37 & 17,67 & 33,30 \\
\hline $\mathrm{SL}_{1} \times \mathrm{RL}_{7}$ & 10,83 & 56,47 & 12,70 & 27,00 \\
\hline $\mathrm{SL}_{1 \times 1} \mathrm{RL}_{10}$ & 11,27 & 48,37 & 17,70 & 28,70 \\
\hline $\mathrm{SL}_{1} \times \mathrm{RL}_{12}$ & 10,33 & 62,63 & 9,43 & 32,70 \\
\hline $\mathrm{SzD}_{5 \%}(6)$ & 0,05 & 0,22 & 0,25 & \\
\hline
\end{tabular}

Table 3. Starch-, protein content, thousand kernel weight of single cross sweet sorghum hybrids (1) Sorghum hybrids, (2) Moisture, (3) Starch, (4) Protein, (5) Thousand kernel weight, (6) LSD $5 \%$.

Minden hibridnél pozitív átlagos, és abszolut heterózishatás volt tapasztalható a keményítôtartalomra nézve. A relatív heterózis értékei 0,49-21,7\% közötti intervallumértékek, a két szülő átlagát a keményítőtartalomra nézve 21,7\%-kal haladta meg az $S L_{1} x R L_{7}$ vonal, amelynek keményítótartalma 56,47\% volt, és az abszolut heterózis is $10,07 \%$. A legmagasabb keményítótartalmat (62,63\%-ot) mutató hibrid az $S L_{1} x R L_{12}$ keményítôtartalomra vetített relatív heterózisa 1,9\% volt, míg abszolut heterózisnak 1,17\%-ot számoltunk. A jobbik szülő átlagát mind fehérje-, mind keményítôtartalomra nézve egyik hibrid sem 
haladta meg, tehát negatív heterózist tapasztaltunk. A jobbik szülő az államilag elismert Ria vonal, míg a vizsgált vonalak és hibridek nem államilag elismertek.

A fehérjetartalomra számított átlagos és abszolut pozitív heterózis az $S L_{1} x R L_{4}$ és az $S L_{1} x R L_{10}$ kétvonalas hibridnél volt megfigyelhető. Az $S L_{1} x R L_{4}$ hibrid fehérjetartalomra számított átlagos heterózisa 18,35\%, míg az abszolut $2,74 \%$ volt. A fehérjetartalma $18,35 \%$ relatív heterózist mutató hibridnek $17,67 \%$ volt. Az $S L_{1} x R L_{10}$ hibrid 3,14\% relatív, míg 0,54\% abszolut heterózist mutatott a fehérjetartalomra nézve. A hibrid fehérjetartalmának 17,7\%-ot mértünk.

Az ezerszemtömegre számítva mind az átlagos heterózis, mind a heterobeltiózis két hibrid esetében volt pozitív (4. táblázat). Az $S L_{1} x R L_{4}$ hibridnél az átlagos relatív heterózis 19,65\%, míg az abszolut heterózis 5,47\%. A hibrid ezerszemtömegre nézve a jobbik szülő átlagát is meghaladta. A heterobeltiózis relatív értéke 8,61\%, míg az abszolut 2,64\%. A kétvonalas cukorcirokhibrid ezerszemtömege $(33,3 \mathrm{~g})$ volt a legnagyobb a vizsgált vonalak között (3. táblázat). Az $S L_{1} x R L_{12}$ hibrid ezerszemtömege 32,7 $\mathrm{g}$, a relatív átlagos heterózis $29,09 \%$, míg az abszolut 7,37\% volt. A jobbik szüló átlagát 6,65\%-kal, míg abszolut heterobeltiózisra számítva 2,04\%-kal haladta meg. Az $S L_{1} x R L_{10}$ hibridnél az átlagos relatív és abszolut heterózis volt tapasztalható, míg a jobbik szüló átlagát nem haladta meg a hibrid az ezerszemtömeget illetốn. A két szülő átlagát 8,32\%-kal múlta felül, az ezerszemtömeg $28,7 \mathrm{~g}$ volt.

A szemek keményítôtartalma növekedett, miközben a fehérjetartalom csökkent. A keményító és a fehérjetartalom alakulása között szoros negatív korrelációt tapasztaltunk $\left(\mathrm{r}=-0,9412^{* * *}\right)$. A lineáris regressziós egyenes képlete a következô: $\mathrm{Y}=-2,0454 \mathrm{x}+81,865$. A keményítótartalom és a nedvesség \%-os értékének változása között közepes negatív kapcsolatot találtunk ( $\left.\mathrm{r}=-0,684^{* *}\right)$. Az egyenes képlete a következó: $Y=-8,0891 \mathrm{x}+148,12$. 
4. táblázat. A heterózis mértéke a NIR készülékkel meghatározott értékekre vonatkozóan a vizsgált hibrideknél

Heterózishatás mértéke a keményítôtartalomra

(2)

\begin{tabular}{|c|c|c|c|c|}
\hline \multirow{4}{*}{$\begin{array}{c}\text { Keresztezések } \\
\text { (1) }\end{array}$} & \multirow{2}{*}{\multicolumn{2}{|c|}{$\begin{array}{l}\text { Heterózis } \\
\text { (5) }\end{array}$}} & \multirow{2}{*}{\multicolumn{2}{|c|}{$\begin{array}{c}\text { Heterobeltiózis } \\
(6) \\
\end{array}$}} \\
\hline & & & & \\
\hline & Átlagos (\%) & Abszolút (\%) & Átlagos (\%) & Abszolút (\%) \\
\hline & $(7)$ & (8) & (7) & (8) \\
\hline $\mathrm{SL}_{1} \times \mathrm{RL}_{4}$ & 6,63 & 3,25 & $-11,08$ & $-6,53$ \\
\hline $\mathrm{SL}_{1} \times \mathrm{RL}_{7}$ & 21,7 & 10,07 & $-4,12$ & $-2,43$ \\
\hline $\mathrm{SL}_{1 \times R L_{10}}$ & 0,49 & 0,24 & $-17,87$ & $-10,53$ \\
\hline $\mathrm{SL}_{1 \times \mathrm{RL}_{12}}$ & 1,9 & 1,17 & $-2,18$ & $-1,4$ \\
\hline
\end{tabular}

Heterózishatás mértéke a fehérjetartalomra

(3)

Keresztezések

Heterózis

Heterobeltiózis

(1)

(5)

(6)

\begin{tabular}{lcccc} 
& $\begin{array}{c}\text { Átlagos (\%) } \\
\end{array}$ & $\begin{array}{c}\text { Abszolút (\%) } \\
(7)\end{array}$ & $\begin{array}{c}\text { Átlagos (\%) } \\
(8)\end{array}$ & $\begin{array}{c}\text { Abszolút (\%) } \\
(7)\end{array}$ \\
\hline $\mathrm{SL}_{1} \mathrm{xRL}_{4}$ & 18,35 & 2,74 & $-5,15$ & $-0,96$ \\
$\mathrm{SL}_{1} \mathrm{xRL}_{7}$ & $-18,22$ & $-2,83$ & $-35,95$ & $-7,13$ \\
$\mathrm{SL}_{1} \mathrm{xRL}_{10}$ & 3,14 & 0,54 & $-23,37$ & $-5,4$ \\
$\mathrm{SL}_{1} \mathrm{xRL}_{12}$ & $-3,28$ & $-0,32$ & $-16,02$ & $-1,8$ \\
\hline
\end{tabular}

Heterózishatás mértéke az ezerszemtömegre

(4)

Keresztezések Heterózis Heterobeltiózis

(1)

(5)

(6)

\begin{tabular}{lcccc} 
& Átlagos (\%) & Abszolút (\%) & Átlagos (\%) & Abszolút (\%) \\
& $(7)$ & $(8)$ & $(7)$ & $(8)$ \\
\hline SL $_{1 \times R L}$ & 19,65 & 5,47 & 8,61 & 2,64 \\
$\mathrm{SL}_{1} \mathrm{xRL}_{7}$ & $-12,42$ & $-3,83$ & $-12,9$ & $-4,00$ \\
$\mathrm{SL}_{1} \mathrm{xRL}_{10}$ & 8,32 & 2,21 & $-6,39$ & $-1,96$ \\
$\mathrm{SL}_{1} \mathrm{xRL}_{12}$ & 29,09 & 7,37 & 6,65 & 2,04 \\
\hline
\end{tabular}

Table 4 . The extent of heterosis concerning the values determined by the NIR device concerning the examined hybrids. (1) Crossings, (2) Heterosis for starch, (3) Heterosis for protein, (4) Heterosis for thousand kernel weight, (5) Heterosis, (6) Heterobeltiosis, (7) Relative heterosis, (8) Absolute heterosis. 


\section{IRODALOM}

Doyle, W.-Parrish, D.-Deyoe, W.: 2010. Nutritive value of protein in high and low protein content sorghum grain as measured by rat performance and amino acid assays. Journal of Nutrition. 88: 66.

Donough, M.-Rooney, L.: 2007. Factors affecting Near Infrared Reflectance (NIR) analysis of whole kernel sorghum, Cereal Quality Laboratory. Texas University Cereal Chemistry. 75. 5: 634-638.

Eyherabide, G.-Robutti, J.-Borras, F.: 1995. Effect of near-infrared transmission-based selection on maize hardness and the composition of zeins. Cereal Chemistry. 73. 6: 775-778.

Hicks, C.-Tuinstra, M.-Pedersen, J.-Dowell, F.-Kofoid, K.: 2002. Genetic analysis of feed quality and seed weight of sorghum inbred lines and hybrids using analytical methods and NIRS. Cereal Chemistry. 78. 4: 412-416.

Joan, R.-Sergio, C.-Dirk, B.-Ostilio, R.-William, L.: 2008. Effect of Grain Sorghum Protein Digestibility on Starch Gelatinization and Enzymatic Conversion to Glucose. ASABE Annual International Meeting. 2-8.

Mohammad, J. M.-Shigekata, Y.-Yoshio, K.: 1979. Protein fractions in Sorghum grain under various levels of nitrogen application. Japan Jour. Crop Science. 49. 3: 502-503.

Mohammad, D.-Cox, P. B.-Posler, G. L.-Kirkham, M. B.-Hussain, A.-Khan, S.: 1993. Correlation of characters contributing to grain and forage yields and forage quality in sorghum (Sorghum bicolor L.). 63. 2: 92-95.

Sherry, A.- Garcia, F.-Anastasia, L.-Bodnar, M.-Scott, P.: 2009. Wide variability in kernel composition, seed characteristics, and zein proWles among diverse maize inbreds, landraces, and teosinte. Theor. Appl. Genet. 119: 1129-1142.

Thokoza, L.: 2005. Evaluation of the heterotic potential of sorghum [Sorghum bicolor (L.) Moench] adapted to the Southern Africa region. Plant Breeding. 1-6.

Yuling, L.-Yanzhao, W.-Mengguan, W.-Xuehui, L.-Jiafeng, F.: 2009. QTL identification of grain protein concentration and its genetic correlation with starch concentartion and grain weight using two populations in maize (Zea mays L.) Journal Genet. 88: $61-67$. 
A szerzők levelezési címe - Address of the authors:

Dr. Pepó Pál-Erdei Éva-Kovácsné Oskolás Henriett-Dr. Tóth Szilárd-Szabó Erzsébet Debreceni Egyetem AGTC Kertészettudományi Intézet

Növényi Biotechnológiai Tanszék

Genetikai és Nemesítési Csoport

Debrecen

Böszörményi út 138.

H-4032 